\title{
Moderation of Local Culture "Pela Guangdong" On the Influence of Personality Towards Organizational Citizenship Behavior and Employee Performance
}

\author{
'Elsina Huberta Aponno, ${ }^{2}$ Nurdin Brasit, ${ }^{3}$ Muh. Idrus Taba, \\ ${ }^{4}$ Muhammad Yunus Amar \\ 'Lecturer, Department of Business Administration, State Polytechnic of Ambon, Indonesia
Email: elslatumaerissaponno@yahoo.com
$\begin{aligned} & { }^{2} 3,4 \text { Lecturer, Department of Management, University of Hasanuddin, Makassar, Indonesia }\end{aligned}$
}

Abstract

The leader must be able to manage the employees with individual values that are different due to differences in their cultural backgrounds. This makes it important to understand that differences in national culture and make generalizations or stereotypical conclusions can not only be a mistake but also can be a problem. Indonesia as a country with diverse cultures is also a challenge in the context of organizational behavior, so the study on local cultural nuance becomes important to continue to be done.

This study aimed to analyze the local culture "pela gandong" of Maluku on the influence of personality towards organizational citizenship behavior and employee performance. The populations were the banking industry employees in the city of Ambon, Maluku province, Indonesia with a sample of 187 . The data were analyzed through structural equation models using LISREL software.

The results showed that; personality had a positive and significant influence towards OCB, personality did not significantly influence employee performance, OCB had a positive and significant influence towards employee performance. The moderation of local culture "pela gandong" strengthens the relationship between personality and OCB. The local culture "pela gandong" did not moderate the relationship between personality and performance. The moderation of local culture "pela gandong" strengthens the relationship between OCB and employee performance.

Keywords: "Pela Gandong” Local Culture, Personality, OCB, Performance.

\section{Background}

Culture has been identified as one of the fields of organizational behavior studies as an interdisciplinary field devoted to understanding and managing employees better. Anthropology that contributes to this (Robbins and Judge, 2014). The cross-cultural analysis also becomes important to do to better understand the behavior in the organization.

Culture becomes one of the interesting things to be explored further in this study. Tsui, et al., (2007) in his meta-analysis of the development of organizational 
behavioral research with national culture as the main variable reveals a number of paradigm development and research methods used, but it also becomes a gap because it occurs mainly in North America and Europe, whereas The 21st century should be a century of international management research. The unique challenge of organizational behavioral research in a cross-national context is to ensure the validity of cultural concept constructs, incorporate other national differentiators to improve the internal validity of the findings and strengthen the research design by leveraging inter-country collaboration so as to enhance external validity. Tsui, et al (2007) then recommends that more research with the characteristics of other countries with cultures different from preference based on existing models (which are mostly US models) and analyzed with other countries that may be different from Americans in the same phenomenon. North America and Europe dominate the global management literature so that Tsui, et al., (2007) encourages more specific research, especially from countries in Asia, South America and other developing countries to fill gaps in global management knowledge.

This is in line with the idea that proposed by Hosftede (1991), that is based on a level of individualism, American that is ranked one of the 50 countries with a score of IDV (individualism index) 91 is having employees with different behavior compares to the employees Indonesia and Pakistan which ranks 47 or 48 with a score of IDV 14. The rating shows America as a country characterized by individualism, while Indonesia is considered the country with the value of collectivism so that conducting the research using American individualist culture model would not be suitable to be applied in countries with a collective value such as in Indonesia. To the present time, there has been also a shift in the dynamic organization of individuals working as teams. Robbins (2006) shows that the team works harder difficulty implemented by many employees in Western countries because they have an individualistic culture and working environment in Western countries have a competitive nature that appreciates individual achievements. Working in a team is predicted more likely to thrive in countries with high collectivity value.

In studying about culture, the concept of ethnic is also known that is often used interchangeably with other cultures and races. Usually, ethnicity used in reference to the group by nationality, culture, or language. Ethnic refers to the quality of ethnic or the affiliation of the group, which is usually characterized in terms of culture (Betancourt and Lopez, 1993). Ethnicity group tends to interact with other ethnic groups, such interactions should not be ignored because it may be a source of cultural influence. Therefore, it is important that the comparative study of ethnic groups identify and measure cultural variables assumed is responsible for the observed differences in psychological phenomena before the difference is attributed to the culture on the basis of group membership (Betancourt and Lopez, 1993).

Indonesia should also do a lot of behavioral studies involving ethnic considering the cultural and ethnic diversity it has. According to Hofstede (1991), Indonesia is categorized as a country with collective values. Although culturally and ethnically diverse, in general, the values contained in the local culture in Indonesia contain the value of collectivism. Kambu et. al, (2012) in his research in Papua shows that the culture of Papua with indicators of work ethos, mutual cooperation, openness, cultural preservation, and consumption patterns can improve performance through OCB.

In the context of the local culture, the people of Maluku, especially in Central Maluku have a tradition "pela gandong" were also quite strong influence people's behavior. "Pela" as a social institution can show how the ancestor of Maluku society 
was without considering the differences that exist between them in the form of cultural differences, social differences and religious differences (Uneputty, 1996). "Pela gandong" (Lokollo et al, 1997) is a union between one village on the island of Ambon with one or several other villages on the island of Ambon, Lease and Seram, unions which is based on a real relationship with the contents and code of conduct unions covered by the agreements both oral and written, in which the parties pledge to submit to the agreement as a legal basis for its implementation from time to time.

Relationship "pela gandong" has a very important effect where all people participate uphold unity and maintain the relationship. Many studies conducted on " pela gandong " but most examines the aspects of sociology anthropological (Sahusilawane, 2004; Uneputty, 1996; Lokollo et al, 1997; Huwae, 1995; Pattiselano, 1999). "Pela gandong" is also widely used in scientific studies but more emphasis on its function to prevent or handle conflicts (Ralahallo 2009; Kadir, 2012; Manuhuttu, 2015; Frost, 2004; Mualim et al, 2014; Hoedodo et al, 2013), community development post-conflict (Tuhuteru, 2014; Sholeh, 2013), development development (Piris and Tilaar, 2014), or integration in educational methods (Tuhuteru, 2014; Matitaputty, 2013). Pela gandong has also been proven to be an interesting field of study not only for local researchers (Sahusilawane, 2004; Uneputty, 1996; Lokollo et al., 1997; Ralahallo, 2009; Manuhuttu, 2015; Huwae, 1995; Pattiselanno, 1999) but it is also concerned by national researchers (Hoedodo et al, 2013; Sholeh, 2013) and international researchers (Bartels, 1977 in Uneputty, 1996; Frost, 2004; Mualim et al., 2014).

The managerial review on this aspect is still very limited. Whereas the values embodied in the culture (of course including "pela gandong" as a local culture) by Hosftede (1991) were able to influence the behavior of the organization. Culture has a prescriptive and descriptive element and involves spontaneous assumptions about how to think, to act, and to feel. Employees bring their culture to the workplace in the form of customs and language. Social culture and organizational culture cooperate each other to affect the values adopted by someone, ethics, attitudes, and expectations (Kreitner and Kinicki, 2014). Hosftede (1991), defines culture as a mental program that is patterned mind (thinking), feeling (feeling), and action (action) or so-called "software of the mind". Mental or cultural programming is developed through a value system that developed in the community, then this value system will be the social norms that influence social behavior. The definition of express that culture including local culture pela gandong influences the behavior of organizational actors.

Aponno, E. H, et al (2017) who first examines the local culture of 'pela gandong' from organizational behavior aspect using quantitative approach. His findings indicate that the local culture 'pela gandong' has a good influence on organizational behavior at the individual level. At the group level, there is no influence, while at the organizational level it brings a bad effect. This illustrates that the local culture 'pela gandong' if it is applied in the correct context will be able to give a good impact. This research would like to try to further explore the influence of local culture 'pela gandong' by involving more varied variables of personality, organizational citizenship behavior, and performance in order to test the preliminary findings that already exist. 


\section{Theoretical Background}

\subsection{Organizational Behavior}

Organizational behavior represents the human management side, not the overall management. In short, organizational behavior is defined as the understanding, prediction, and management of human behavior in organizations (Luthans, 2005). Organizational behavior is also defined as an activity to study the behavior of individuals and groups within organizations (Heath and Sitkin, 2001). Another definition of organizational behavior is the field of study that investigates the effects individuals, groups, and structures have on organizational behavior aimed at applying such knowledge to enhance the effectiveness of an organization (Robbins and Judge, 2014a).

\subsection{Personality}

Personality shapes each individual's behavior, so if you want to be better in understanding someone's behavior in the organization; it is useful to know something about personality (Robbins and Judge, 2014a). The most common personality definition was made by Gordon Allport almost 70 years ago that personality is a dynamic organization in the individual psychological system that determines how to adapt uniquely to its environment (Robbins and Judge, 2014a) Personality is a combination of physical and mental characteristics and it is an indication of how an individual sees, thinks, behaves and feels (Rashidi and Tafreshi, 2015).

\subsection{Performance}

Organizations require individuals with a performance that can help the organization to achieve competitive advantage. Performance is also important for the individual because the ability to get the job done well can be a source of satisfaction and pride. In addition, if performance is recognized by others in the organization, it will often be rewarded with financial and other benefits. Performance is the main (though not the sole) requirement for career development and success in the labor market. While there may be exceptions, high performing employees are more easily promoted within an organization and generally have better career opportunities than low-performing employees (Sonnentag and Frese, 2002).

\subsection{Organizational Citizenship Behavior (OCB)}

Sonnentag and Frese (2002) have identified organizational citizenship behavior (OCB) or organizational civic behavior as a form of extra-role performance in addition to positive organizational behavior and proactive behavior. The organizational citizenship behavior (OCB) concept was introduced by Organ in 1977 and was first published in the form of empirical research by Smith, Organ, and Near in 1993 (Moon et al., 2004). Organ defines OCB as a free (discretionary) individual behavior, which is not directly and explicitly rewarded by a formal reward system, and which in whole encourages the effectiveness of organizational functions (Alizadeh et al. 2012). It is free and voluntary since such behavior is not required by role requirements or job descriptions which are clearly required under contract with the organization; But as a personal choice (Podsakoff et al., 2000).

\subsection{Culture in Organizational Behavior}

Hofstede (1991) defines culture as a pattern of thoughts, feelings, and actions for social groups, which distinguishes it from other social groups. Cultural concepts 
derived from mental programs which are distinguished in three levels, namely; 1) The universal level, that is the mental program held by all human beings and attached to the human self, 2) The collective level, that is the mental program is owned by some, not all human beings. At this level, special mental programs are in groups or categories and can be learned. 3) The individual level, that is, the unique mental program is owned by only one or two people who will not have the same mental program. At this level, a small mental program is embedded in human beings, and others can be learned from other communities, organizations or groups.

Culture is a set of beliefs and values about what is liked and disliked in one community of people, as well as a set of formal and informal practices to support values. Culture has a prescriptive and descriptive element and involves spontaneous assumptions about how to think, act, and feel. Culture overrides national ties. Key aspects of the social culture such as behavior and language, are brought to the workplace by individuals. Society culture and an organizational culture where he works both influence one's own values, ethics, attitudes, and expectations (Kreitner and Kinicki, 2014a). Hosftede (1991), defines culture as a mental program of thinking, feeling, and action or called "software of the mind". This mental or cultural programming is developed through a value system that develops in society, then this value system will become the social norms that influence social behavior. The definition expresses that culture influences the behavior of the organizers.

\subsection{Recognizing Pela Gandong as Mollucan Culture}

Pela gandong is a social foundation for people in Central Maluku, especially Seram Island, Ambon, and Lease (Lokollo, et al., 1997; Uneputty, 1996). Since long ago this social foundation has been living and developing as a glue of social relations between one village and another village, both Muslim and Christian (Sahusilawane, 2004) and has a function to regulate the social interaction of rural communities in various fields (Uneputty, 1996).

Simply pela is formulated as a familial bond between two or more villages whereas gandong is a brotherly relationship between two or more villages based or backed up by the existence of genealogical relations between the villages were the ancestors of the villages came from (Uneputty, 1996). That is why it marriage among its citizens in both villages that have gandong relationship strictly forbidden..

There are several reasons for the existence of pela relations as a tradition as mentioned by experts (Uneputy, 1996, Bartels, 1977 in Ralahallo 2012, Sahusilawane, 2004), among others: first, pela relations as a recompense from a village to another village where they had helped him in times of war or natural disasters. Second, the pela happened because there is a relationship of brotherhood between the villages according to the story of their ancestors, that they are siblings. Third, pela relationship happened because of the occurrence of extraordinary things. The power of binding plea agreement (Pela Law) is based on the principle of "sei hale hate, hatu hale sei". Can be translated "sapa bale batu, batu bale dia" which means "what the elders make, must be maintained".

There are four basic things underlying pela gandong: the villages that have the duty to help each other on the emergency (war, natural disaster). If requested, one village must provide assistance to another village, such as to help them build in an interesting construction like the construction of schools, mosques, or churches. If a man is visiting the village where becoming his plea, then the people of the village must feed him. He can bring any food or fruits from that village without permission. Because the pela is considered to be in the blood, then two such persons are 
forbidden for marriage. For those who break such provision, then he will get punishment from the ancestors who pledge pela. For example, a person or his descendant may fall ill or even die if they break that provision. If anyone breaks the taboo for marriage, then they will be arrested and then made to walk around the countries with only clothes that made by coconut leaves, while all residents of the land will berate him.

Kreitner and Kinicki (2014a) reveal that cultural processes influence organizational behavior, for example, employees bringing their culture to the workplace in the form of habits and languages that also affect individual values, ethics, attitudes, assumptions, and expectations. Along with the opinion of Hofstede (1991) who states that culture as a mental program in a group of people becomes the basis for forming the characteristic of people a group. "Pela gandong" is a cultural process that can affect the personality and individual values of a person in his workplace. Kinship system that is built based on the values of pela gandong according to Uneputty (1996) have been able to establish the identity of Maluku people what is called as common sense of belonging (sense of community), common sense of unity (a sense of unity and oneness), the common sense of responsibility (sense of responsibility).

\section{Hypothesis}

This study aimed to prove that the local culture 'pela gandong' affect the relationship between personality, organizational citizenship behavior (OCB) and employee performance.

\subsection{Direct Influence Between Personality, OCB, and Performance}

In general, personality was found to be positively associated with OCB (Hakim, et al., 2014; Malik, et al., 2013; Yi-Min, et al., 2012; Darsana, 2013). The personal relationship with OCB on several dimensions was found to have a positive effect. Extraversion, agreeableness consistently found to be positively associated with OCB by Rashidi and Tafreshi (2015), Golafshani and Rahro (2013), Kumar, et al. (2009). Conscientiousness and openness to experience were found to be positively and significantly associated with OCB by Rashidi and Tafreshi (2015) and Kumar et al., (2009).

A meta-analysis performed by Judge and llies (2002) showed that personality based on five-factor model had a positive effect on performance. All dimensions found to be significantly related to performance, neuroticism and conscientiousness consistently show the strongest significant relationship with performance. This is in line with the findings of Hakim et al. (2014) that the relationship of personality toward the performance is positive and significant. In a more in-depth study of the relationship of personality dimensions with OCB, Misha, et al (2015) found that only conscientious and agreeableness that has a positive and significant effect on performance.

The various literature generally shows empirical evidence of OCB relationships with performance in general, where OCB has a positive effect on performance (Podsakoff et al. (2000).) Robbins and Judge (2014a) also revealed that the fact that an organization with an employee with a good OCB will have better performance than other organizations. OCB in general in empirical approach also found to be positively related to employee performance level as well as 
organizational performance (Kambu, et al., 2012; Harwiki, 2013; Maharani, et al., 2013; Hakim, et al, Yaw-Chieh, 2013; Sani and Maharani, 2012; Muhdar, et al., 2015; Andrew and Cazares, 2014.) The influence of OCB on the performance dimension is expressed by Cheng, et al. (2012) which states that OCB is related Positive with product quality.

Based on the theoretical descriptions and empirical findings, the hypothesis developed as follows:

1a. Personality has a positive effect on $O C B$

1b. Personality has a positive effect on employee performance

1c. OCB has a positive effect on employee performance.

\subsection{Moderation of Culture on the Relationship Between Personality, OCB, and Performance}

The role of culture as a moderator variable between personality and OCB is found in Xian-Xu's (2004) study that examines hierarchy and egalitarianism as a form of individualism as a cultural variable. His research proves that hierarchy/egalitarianism moderates the relationship between conscientiousness and OCB-O where positive relationships are stronger when the hierarchy is low and egalitarianism is high. The results do not prove that hierarchy/egalitarianism moderates the relationship between agreeableness and OCB-O where positive relationships are stronger when the hierarchy is low and egalitarianism is high. Aponno, Aponno, E.H., et al (2017) found that the local culture 'pela gandong' strengthen the relationship between personality and OCB.

Yakazai, AM, and Jan, MT (2015) in his research that is aimed to examine the impact of personality on the performance of the sales force by considering the mediating role of customer orientation, as well as exploring the role of culture moderates found that differences in cultural background of sales force affect sales performance.

The previous theoretical review and the empirical data are the basis of formulating the hypotheses on the study as follows:

2a. Local culture "pela gandong" moderate the relationship of personality with OCB

$2 b$. Local culture "pela gandong" moderate the relationship of personality with performance

2c. Local culture "pela gandong" moderate the relationship of OCB with performance

\section{Research Methodology}

A population that becoming the unit of analysis in this research is employees of the banking industry in Ambon city, Maluku province, Indonesia. This study uses pela gandong as a moderating variable so that the samples used are employees of the banking industry in the city of Ambon either having a cultural background of pela gandong who come from Ambon, Lease, and Seram island also including those with no pela gandong. .

The main instrument in collecting data in this study is to provide a structured questionnaire adapted from various previous studies that are considered to have been tested for reliability and validity. Personality is measured by 7 indicators developed by John, O. P. (1991); OCB is measured by 8 indicators developed by 
Podsakoff, et al. (1997); And employee performance is measured by 10 indicators developed by Koopmans, et al. (2012). The answer the answer from the question is changed to the Likert interval scale for the needs of testing modeling. Respondents' answers have a score range of $1-5$ values where the value of 1 for the answer strongly disagree and the value of 5 for the answer strongly agree. The number of sample used is 200 . The questionnaire is returned and is worthy of use in the next analysis process of 187.

Data analysis techniques in this study using structural equation model (SEM) with the help of software listed. For local culture pela gandong which is a moderation variable, the sample will be separated into two parts, namely the sample group with the cultural background of pela gandong and the sample group without the cultural background of pela gandong.

\section{Results}

\subsection{Goodness of Fit Measurement}

The goodness of fit measurement is done to answer questions; whether the indicator has been conceptually unidimensional, which means that empirically the overall measurement model is appropriate, fit with the data, the indicators in the model only measure a construct, and the measurement error between the uncorrelated indicator or the covariance error is zero.

Table 1. Goodness of Fit Measurement Test Results

\begin{tabular}{|c|c|c|c|c|c|c|}
\hline \multirow{2}{*}{ Variable } & \multirow{2}{*}{$\begin{array}{c}\text { Goodness } \\
\text { Of Fit }\end{array}$} & \multirow{2}{*}{$\begin{array}{c}\text { Cut-off } \\
\text { Value }\end{array}$} & \multicolumn{2}{|r|}{ Pre } & \multicolumn{2}{|c|}{ After Modification } \\
\hline & & & Result & Evaluation & Result & Evaluation \\
\hline \multirow{6}{*}{ Personality } & $p$ value & $\geq 0,05$ & 0,00 & Less Fit & 0,26 & Fit \\
\hline & GFI & $\geq 0,90$ & 0,69 & Less Fit & 0,99 & Fit \\
\hline & RMSEA & $\leq 0,08$ & 0,32 & Less Fit & 0,041 & Fit \\
\hline & AGFI & $\geq 0,90$ & 0,39 & Less Fit & 0,94 & Fit \\
\hline & TLI/NNFI & $\geq 0,90$ & 0,80 & Marginal Fit & 1,00 & Fit \\
\hline & NFI & $\geq 0,90$ & 0,86 & Marginal Fit & 1,00 & Fit \\
\hline \multirow{6}{*}{$\begin{array}{c}\text { Organizational } \\
\text { Citizenship } \\
\text { Behaviour }\end{array}$} & $p$ value & $\geq 0,05$ & 0,00 & Less Fit & 0,52 & Fit \\
\hline & GFI & $\geq 0,90$ & 0,90 & Fit & 0,99 & Fit \\
\hline & RMSEA & $\leq 0,08$ & 0,13 & Less Fit & 0,00 & Fit \\
\hline & AGFI & $\geq 0,90$ & 0,81 & Marginal Fit & 0,96 & Fit \\
\hline & TLI/NNFI & $\geq 0,90$ & 0,95 & Fit & 1,00 & Fit \\
\hline & NFI & $\geq 0,90$ & 0,95 & Fit & 0,99 & Fit \\
\hline \multirow{6}{*}{ Performance } & $p$ value & $\geq 0,05$ & 0,00 & Less Fit & 0,008 & Less Fit \\
\hline & GFI & $\geq 0,90$ & 0,74 & Less Fit & 0,96 & Fit \\
\hline & RMSEA & $\leq 0,08$ & 0,21 & Less Fit & 0,07 & Fit \\
\hline & AGFI & $\geq 0,90$ & 0,60 & Less Fit & 0,89 & Marginal Fit \\
\hline & TLI/NNFI & $\geq 0,90$ & 0,85 & Marginal Fit & 0,98 & Fit \\
\hline & NFI & $\geq 0,90$ & 0,87 & Marginal Fit & 0,98 & Fit \\
\hline
\end{tabular}

Initial measurements show that the model is not fit because it does not meet many criteria. After modification of all variables, the results show that the model theoretically corresponds to the empirical data or the model has fit. Although the performance variable of the AGFI value is in the range of marginal fit and $p$-value is still not fit but many other criteria have been qualified. 


\subsection{Validity and Reliability}

Testing validity is intended to ensure how well an instrument measures a concept that should be measured. The following table shows the results of the validity test:

Table 2. Validity Test Result

\begin{tabular}{|c|c|c|c|c|}
\hline Variable & Indicator & $\begin{array}{c}t \text { value } \\
(>1,96)\end{array}$ & $\begin{array}{c}\text { Standardized } \\
\text { factor loading } \\
(>0,45)\end{array}$ & Evaluation \\
\hline \multirow{7}{*}{ Kepribadian } & $\mathrm{X} 1.1$ & 8,97 & 0,64 & Good \\
\hline & $\mathrm{X} 1.2$ & 10,83 & 0,71 & Good \\
\hline & $\mathrm{X} 1.3$ & 14,17 & 0,85 & Good \\
\hline & $\mathrm{X} 1.4$ & 15,34 & 0,91 & Good \\
\hline & $\mathrm{X} 1.5$ & 15,13 & 0,90 & Good \\
\hline & $\mathrm{X} 1.6$ & 13,18 & 0,82 & Good \\
\hline & $\mathrm{X} 1.7$ & 13,93 & 0,85 & Good \\
\hline \multirow{8}{*}{$\begin{array}{l}\text { Organizational } \\
\text { Citizenship } \\
\text { Behaviour }\end{array}$} & Y1.1 & 13,09 & 0,83 & Good \\
\hline & Y1.2 & 13,70 & 0,85 & Good \\
\hline & Y1.3 & 12,69 & 0,81 & Good \\
\hline & Y1.4 & 9,53 & 0,66 & Good \\
\hline & Y1.5 & 10,45 & 0,70 & Good \\
\hline & Y1.6 & 11,39 & 0,74 & Good \\
\hline & Y1.7 & 13,97 & 0,86 & Good \\
\hline & Y1.8 & 5,15 & 0,38 & Not Good \\
\hline \multirow{10}{*}{ Kinerja Individu } & Y2.1 & 9,34 & 0,64 & Good \\
\hline & Y2.2 & 9,95 & 0,68 & Good \\
\hline & Y2.3 & 11,76 & 0,77 & Good \\
\hline & Y2.4 & 10,79 & 0,74 & Good \\
\hline & Y2.5 & 7,99 & 0,57 & Good \\
\hline & Y2.6 & 11,48 & 0,75 & Good \\
\hline & Y2.7 & 8,74 & 0,63 & Good \\
\hline & Y2.8 & 12,67 & 0,81 & Good \\
\hline & Y2.9 & 12,92 & 0,82 & Good \\
\hline & Y2.10 & 9,30 & 0,64 & Good \\
\hline
\end{tabular}

The results of the analysis shown in Table 2 shows that some indicators not valid because it does not meet the validity requirements of t-value> 1.96 and factor loading $>0.45$ which are; OCB indicator $\mathrm{Y} 1.8$. Invalid indicators must be removed and not used in the next analysis process.

Reliability is closely related to the consistency of manifest variables in measuring its latent constructs. Reliability test results show the value of construct reliability for the 0.93 personality variable, 0.90 OCB and individual performance 0.91 . The result of the analysis shows that all variables have good reliability with construct reliability value above 0.7 . Thus all manifest variables (indicators) are expressed consistently in measuring their latent constructs (variables).

\subsection{Testing Hypothesis}

Structural model testing should be done before the hypothesis test. In this research, the structural model test is the goodness of fit measurement test conducted on the main model, the model for the pela gandong group sample and the model for the sample group without pela gandong. The initial test results for the three models are not yet fit so modifications indices should be made. After the modification suggestion, the model has been declared eligible for further analysis. 
A hypothesis test is done to see the direct and indirect influence and influence of moderation which result can be seen in the following table:

Tabel 3. Summary of Hypothesis Test Result

\begin{tabular}{|c|c|c|c|c|c|c|c|c|c|c|}
\hline \multicolumn{11}{|c|}{ Direct Influence } \\
\hline Hip. & \multicolumn{2}{|c|}{$\begin{array}{l}\text { Independent } \\
\text { Variable }\end{array}$} & \multicolumn{2}{|c|}{$\begin{array}{l}\text { Dependent } \\
\text { Variable }\end{array}$} & \multicolumn{2}{|c|}{ Standardize } & \multicolumn{2}{|c|}{$\begin{array}{c}\text { CR } \\
(\mathrm{t} \text { value }>1,96)\end{array}$} & \multicolumn{2}{|r|}{ Conclusion } \\
\hline $\mathrm{H} 1 \mathrm{a}$ & \multicolumn{2}{|c|}{ Personality } & \multicolumn{2}{|c|}{ OCB } & \multicolumn{2}{|c|}{0,21} & \multicolumn{2}{|c|}{1,99} & \multicolumn{2}{|r|}{ Significant } \\
\hline $\mathrm{H} 1 \mathrm{~b}$ & \multicolumn{2}{|c|}{ Personality } & \multicolumn{2}{|c|}{ Performance } & \multicolumn{2}{|c|}{0,13} & \multicolumn{2}{|c|}{1,31} & \multicolumn{2}{|r|}{ Not significant } \\
\hline $\mathrm{H} 2 \mathrm{~d}$ & \multicolumn{2}{|l|}{ OCB } & \multicolumn{2}{|c|}{ Performance } & \multicolumn{2}{|c|}{0,76} & \multicolumn{2}{|c|}{6,50} & \multicolumn{2}{|r|}{ Significant } \\
\hline \multicolumn{11}{|c|}{ The Influence of Local Culture Moderation "Pela Gangdong" } \\
\hline \multirow[t]{2}{*}{ Hip. } & \multirow{2}{*}{$\begin{array}{l}\text { Independent } \\
\text { Variable }\end{array}$} & \multicolumn{2}{|c|}{ Dependent } & \multicolumn{3}{|c|}{$\begin{array}{l}\text { Group with "Pela } \\
\text { Gandong" Culture }\end{array}$} & \multicolumn{3}{|c|}{$\begin{array}{l}\text { Group without "Pela } \\
\text { Gandong" Culture }\end{array}$} & \multirow[t]{2}{*}{ Conclusion } \\
\hline & & & riable & $\begin{array}{c}\text { Standar } \\
\text {-dize }\end{array}$ & $\begin{array}{c}\text { CR } \\
(t \text { value })\end{array}$ & Ket & $\begin{array}{c}\text { Standar } \\
\text {-dize }\end{array}$ & $\begin{array}{c}\mathrm{CR} \\
\text { (t value) }\end{array}$ & Ket & \\
\hline $\mathrm{H} 4 \mathrm{a}$ & Personality & & CB & 0,32 & 2,41 & Sig & 0,21 & 1,72 & $\begin{array}{l}\text { Not } \\
\text { Sig. }\end{array}$ & $\begin{array}{l}\text { Moderation } \\
\text { (strenghten) }\end{array}$ \\
\hline $\mathrm{H} 4 \mathrm{~b}$ & Personality & & $\begin{array}{l}\text { rfor- } \\
\text { ance }\end{array}$ & 0,24 & 1,90 & $\begin{array}{l}\text { Not } \\
\text { Sig. }\end{array}$ & 0,12 & 1,12 & $\begin{array}{l}\text { Not } \\
\text { Sig. }\end{array}$ & $\begin{array}{c}\text { No } \\
\text { Moderation }\end{array}$ \\
\hline $\mathrm{H} 4 \mathrm{c}$ & OCB & & $\begin{array}{l}\text { rfor- } \\
\text { ance }\end{array}$ & 0,59 & 6,76 & Sig & 0,74 & 5,03 & Sig & $\begin{array}{l}\text { Moderation } \\
\text { (strenghten) }\end{array}$ \\
\hline
\end{tabular}

Summary of hypothesis test results are presented in the following figure :

Picture 1. Summary of Hypothesis Test Result

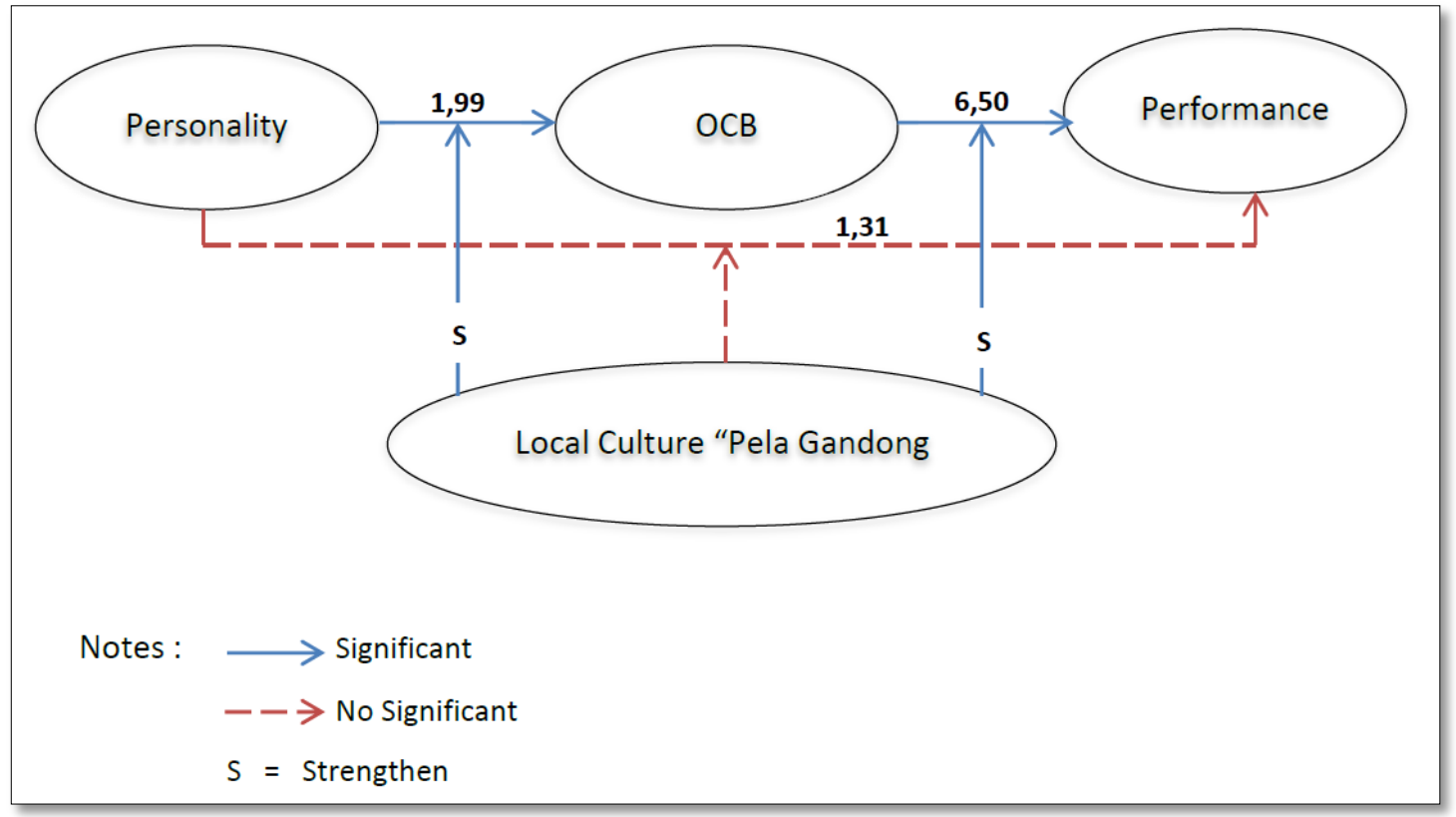


Hypothesis test results on the direct influence of personality, OCB, and the performance are as follows; Hypothesis 1a accepted; Personality is positively related to OCB. It is based on use values path coefficient of 0,21 critical value ( $t$ value) of 1.99 is greater than the $t$-table value of 1.96 at a significance level of 0.05 . Hypothesis $1 \mathrm{~b}$ rejected; Personality is positively related to OCB. It is based on the value of path coefficient of 0,13 . Furthermore, the critical value (t-value) will show the significance of the effect; the value is 1,31 is smaller than the t-table value of 1.96 at a significance level of 0.05 . In conclusion, the personality has no effect on employee performance. Hypothesis 1c is accepted; OCB has a positive effect on performance. It is based on the value of path coefficient of 0,76 , which means the amount of direct influence of OCB towards the performance. Then the critical value ( $t$-value) will show the significance of the effect, of which the value of 6,50 is greater than the $t$-table value of 1.96 at a significance level of 0.05 .

Hypothesis test results of local culture 'pela gandong' as the moderation that is always moderate personality relationship, OCB, and the performance are as follows: Hypothesis $2 \mathbf{a}$ accepted; local culture "pela gandong" moderated the relationship between personality and OCB. It is based on hypothesis test results; $t$-value sample group pela gandong 2,41 is greater than the sample group without "pela gandong" 1.72. Hypothesis 2b rejected; local culture "pela gandong" moderated the relationship between personality and performance. It is based on the hypothesis test results that the $t$-value group "pela gandong" were insignificant that is to 1,90 (less than 1.97), as well as $t$-value of the sample group without "pela gandong" 1.12 (less than 1,97). Hypothesis 2c received; Local culture "pela gandong" moderated the relationship between OCB relationship and performance. It is based on hypothesis test results; $t$-value sample group "pela gandong" 6,76 greater than the sample group without "pela gandong" 5.03.

\section{Discussion and Conclusion}

Hypothesis 1a "personality is positively related to OCB" is acceptable because it is empirically proven in this study. The conclusion of this hypothesis test results is the better personality of employees of the banking industry in the city of Ambon, the better his OCB. This study uses seven indicators to measure personality. The influence of personality indicators on OCB can be described as follows: employees of the banking industry in Ambon City who see themselves as being able to arouse the morale of other employees, easy to get along and be affable, unselfish, cooperative with others, emotionally stable, curious about many different things, as well as having an active imagination will have a good OCB. In general, the results of this study are in line with some of the findings of previous research. Judge, et al., (2014); Sjahruddin, et al., (2013), Malik, et al., (2013), Yi-Min, et al., (2012) and Darsana (2013), each in his study found a positive influence of personality on organizational citizenship behavior.

Hypothesis test results show personality does not significantly affect the performance so that hypothesis 2 a rejected because empirically cannot be proofed in this study. The effect of a valid indicator of performance can be described as follows: the employees of the banking industry in Ambon City who see themselves as an uplifting person, sociable, selfless, cooperative, emotionally stable, curious about things and having an active imagination has no significant effect on the employee's performance. The fact that personality has no significant effect on the 
performance of banking employees in the city of Ambon is the tendency of employees to be too careful because the work in the banking world requires high accuracy. The Error that teller made when the counting the customers money who make a withdrawal for example; will make it necessary to change the difference due to the error. This will make the teller very careful when serving the customer. Although this caution has a positive influence on performance (Misha et al., 2015, Judge, Ilies, 2002; Bartone, et al., 2009), but caution also has disadvantages. Robbins and Judge (2008a) argue that individuals with such characteristics cannot adapt well to dynamic contexts. Individuals like these are usually oriented on work performance so that they experience more difficulty than the less cautious individuals learning complex skills in the early stages because their focus is on working rather than learning better. Thus, individuals with a cautious nature are not very creative, even though they are creative, whereas both of these are also needed by individuals to achieve the best performance. The results of this study show that personality has no significant effect on performance, similar to Darsana findings (2013) which states that the personality and organizational culture does not significantly affect employee performance. Misha, et al. (2015) in his research to examine the effects of personality on performance only found a positive and significant influence on the dimensions of the nature of prudence and easy to agree. Whereas in the extraversion dimension, emotional and open stability with the new thing is found as a not significant influence.

Hypothesis test results in this study showed that OCB has a positive and significant effect on individual performance. The effect of a valid OCB indicator on individual performance can be described as follows: an employee who while working is always willing to work with others to complete the job, willing to give time to help others who are facing work problems, helping others who have heavy workloads, not taking extra rest, always on time at work, Always doing unsolicited work but helping the company image and always adapt to changes the company will have a good performance. Some of the findings also support the above findings which are also used as the basis for the development of hypotheses in this study are Kambu, et al. (2012: Harwiki (2013), Boerner, et al. (2007), Maharani, et al., (2013), Hakim, et al., (2014); Yung (2013); Sani and Maharani (2012); Muhdar , Et al. (2015); Andrew and Cazares (2014) that the OCB has a positive and significant influence on performance or OCB improving performance.

. This study shows that there is an influence of moderation of pela gandong culture on the personal relationship with OCB where its moderating influence is strengthening the personal relationship with OCB. The effect of a valid personality indicator on hypothesis test results that the local culture pela gandong strengthen the influence of personality on OCB can be described as follows: employees of the banking industry in the city of Ambon who see themselves as a person who is able to raise the spirit of other employees, easy to get along and outgoing, selfless, like working with others, emotionally stable, curious with many different things and have an active imagination Will have an OCB or good organizational citizenship behavior and the local pela gandong culture will strengthen that influence. The results of this study are in line with the empirical findings of Xian Xu (2004) who found hierarchy/egalitarianism as cultural indicators moderating the relationship between conscientiousness as an indicator of personality with OCB-O where positive relationships are stronger when the hierarchy is low and egalitarianism is high.

The result of this study shows the influences of local culture "pela gandong" modernization that strengthens the relationship between OCB and performance. 
Effect of OCB indicators that are valid towards the hypothesis test result can be described as follows: employees of the banking industry in the city of Ambon, which was willing to work, willing to help others who have problems of work, helping others who have a heavy workload, do not take extra rest, timely in workplace, always working to develop the image of the company, and is able to adapt to changes in the company will have a good performance and the relationship is not influenced by local cultural "pela gandong" background.

Local culture "pela gandong' in this study is proved to have a moderating influence that strengthens the relationship between OCB and performance. Effect of valid indicators of personality towards the results of hypothesis testing that the local culture "pela gandong" strengthen the influence of personality on OCB can be described as follows: employees of the banking industry in the city of Ambon, which see themselves as capable of stimulating other employees, sociable and outgoing, unselfish itself, like working with other people, emotionally stable, like the curious with a lot of different things and have an active imagination would have good OCB and the local culture "pela gandong" will strengthen the influence. The results are consistent with the empirical findings of Xian $\mathrm{Xu}$ (2004) that found hierarchy/egalitarianism as indicator cultural moderation the relationship between conscientiousness as an indicator of personality with OCB-O where a stronger positive correlation when the hierarchy is low and high egalitarianism.

\section{Implications, Limitations, Suggestions For Future Research}

Giving empirical evidence about the influence direct influence of personality, OCB, and performance and moderating role of local culture "pela gandong". The results of this study are also expected to be used as an additional reference, especially on how the cultural relationship with employee behavior in countries other than North America and Europe for further research. The result of this research is expected to provide guidance to the management company about how the local culture "pela gandong" can affect the personality of employees to work beyond his role as the emergence of OCB as well as how these behaviors can influence the performance of individuals.

In the implication, this study has various limitations. This study used the individual as a sample. Personality variable, transformational leadership, organizational justice, OCB, and employee performance are measured based on the employee's perceptions. Self-assessment by these respondents is susceptible to be biased because assessment results may be not objective. The novelty of this research is in the effort to see the influence of moderation of pela gandong culture against other variables developed in research model. Limiting the research sites for only in Ambon city can cause bias on the results of research and causing generalization for research results. Research samples that are limited only to employees of the banking industry which is can categorize as small one can also cause bias and problems in generalizing the results of the study.

. In the future, it is expected that more research on local pela gandong culture will be expected to become more accurate construct in measuring its influence on other variables especially in the scope of organizational behavior study. Future research samples are also expected to be more diverse as well as larger numbers so as to reduce bias and problems on generalization of research results 


\section{References}

Andrew, S. A. dan Cazares, F. L., 2015. Mediating Effect of Organizational Citizenship Behavior on Organizational Performances: Empirical Analysis of Public Employees in Guadalajara, Mexico. EconoQuantum, 12(2):71-92

Aponno, E. H., Brasit., N., Taba, M. I., and Amar, M. Y., 2017. Factors That Influence Organizational Citizenship Behavior And Employees Performance With Local Culture Moderation "Pela Gandong". Scientific Research Journal (SCIRJ), $\mathrm{V}(\mathrm{VI}): 10-26$.

Alizadeh, Z., Darvishi, S., Nazari, K., dan Emami M. 2012. Antecedents and Consequences of Organizational Citizenship Behaviour (OCB). Interdisciplinary Journal Of Contemporary Research in Business, 3(9):494505.

Betancourt, H. dan Lopez, R. 1993. The study of Culture, Ethnicity, and Race in American Psychology. American Psychologist, 48(6):629-637.

Cheng Ling Tai., Che-Ming, Chang., Jhao-Yu, Hong., and Li-Chun, Chen., 2012. Alternative models for the relationship among leadership, organizational citizenship behavior, and performances: a study of new product development teams in Taiwan. Procedia Social and Behavioral Sciences, 57:511-517

Darsana, M., 2013. The Influence of Personality and Organizational Culture on Employee Performances Through Organizational Citizenship Behavior. The International Journal of Management, 2(4):35-42

Frost, N., 2004. Adat di Maluku: Nilai Baru atau Eksklusivisme Lama?. Antropologi Indonesia, 74:1-11

Golafshani, M. R. dan Rahro, M., 2013. Identification of Personality Traits Affecting on Development of Organizational Citizenship Behavior. Middle-East Journal of Scientific Research. 16(2):274-281

Hakim, W., Nimran U., Haerani, S., dan Alam, S., 2014. The antecedents of Organizational Citizenship Behaviour (OCB) and Their Effect on Performance; Study on Public University in Makassar, South Sulawesi, Indonesia. Journal of Business and Management, 16(2):5-13

Harwiki, W. 2013. The Influence of Servant Leadership on Organization Culture, Organizational Commitment, Organizational Citizenship Behavior and Employees' Performance (Study of Outstanding Cooperatives in East Java Province, Indonesia). Journal of Economic and Behaviour Studies, 5(12):876885.

Heath, C., dan Sitkin, S. B., 2001. Big-B versus Big-O: What is Organizational About Organizational Behavior?. Journal of Organizational Behavior, 22:43-58 
Hoedodo, T.S.B., Surjo, J., Qodir, Z., 2013. Local Political Conflict and Pela Gandong Amidst the Religious Conflict. Journal of Government and Politics, 4(2):336-349

Hofstede, G. 1991. Cultures and Organisations, Software of the Mind. Intercultural cooperation and its importance for survival. London: McGraw-Hill Book Company.

Huwae, S., 1995. Divided Opinions About Adat Pela: A Study Of Pela TamilouwSiriSori-Hutumuri. Cakalele, 6:77-92

John, O. P., dan Srivasta, S., 1999. The Big-Five Trait Taxonomy: History, Measurement, and Theoretical Perspectives. In L. Pervin and O. P. John (Eds.), Handbook of personality: Theory and research ( $2^{\text {nd }}$ ed.), page 102138, New York: Guilford (in press)

Judge, T. A., dan Ilies, R., 2002. Relationship of Personality to Performance Motivation: A Meta-Analytic Review. Journal of Applied Psychology, 87(4):797-807

Kadir H. A. 2012. Sapa Bale Batu, Batu Bale Dia; Politik Revivalism; Tradisi Siwalima Orang Ambon Pasca Konflik. Lakon, Jurnal Kajian Sastra dan Budaya, 1(1):61-75.

Kambu, A., Troena, E.A., Surachman dan Setiawan, M. 2012. Influence of LeaderMember Exchange, Perceived Organizational Support, Papua Ethnic Culture and Organizational Citizenship Behavior toward Employee Performances of Workers in Papua Provincial Secretary Office. Journal of Business and Management, 5(4):31-38.

Koopmans, L., Bernards, C., Hildebrandt, V., van Buuren, S., van der Beek, A. J., dan de Vet, H. C. W. 2013. Development of an Individual Work Performance Questionnaire. International Journal of Productivity and Performance Management, 62(1):6-28

Kumar, K., Bakhshi, A., dan Rani, E., 2009. Linking the "Big Five Personality Domains to Organizational Citizenship Behavior. International Journal of Psychological Studies, 1 (2):73-81

Kreitner, R. dan Kinicki, A. 2014a. Perilaku Organisasi - Organizational Behaviour. Edisi 9, Buku 1. Jakarta: Salemba Empat.

Kreitner, R. dan Kinicki, A. 2014b. Perilaku Organisasi - Organizational Behaviour. Edisi 9, Buku 2. Jakarta : Salemba Empat.

Lokollo, J. E., Pattiruhu, C. M., Lestaluhu, M., Timisela, Iz., Limahelu, D., Limahelu, L., Leatemia, J., Leasa G., 1997. Seri Budaya Pela Gandong dari Pulau Ambon. Ambon : Lembaga Kebudayaan daerah Maluku.

Luthans, F. 2005. Perilaku Organisasi. Edisi sepuluh. New York: McGraw-hill. 
Maharani, V., Toerna, E. A., dan Noermijati, 2013. Organizational Citizenship Behaviour Role in Mediating The Effect Of Transformational Leadership, Job Satisfactio on Employee Performance: Studies in PT Bank Syariah Mandiri Malang East Java. International Journal of Business and Management, 8(17):1-12

Malik, M. E., Ghafoor, M. M., dan Iqba, H. K., 2012. Leadership and Personality Traits as Determinants of Organizational Citizenship Behavior (OCB) in Banking Sector of Pakistan. World Applied Sciences Journal, 20(8):1152-1158

Manuhutu, R., Purwiyastuti, W., dan Widiarto, T., 2015. Budaya Pela Gandong Di Negeri Haria Sebagai Alat Pemersatu Dan Perdamaian Orang Maluku Tengah. Widyasari, 17(2):100-105

Matitaputty, J. K., 2013. Pendidikan Karakter Melalui Penggalian Nilai-Nilai Kearifan Lokal budaya Pela Gandong Di Maluku. Jurnal Pendidikan "Jendela Pengetahuan", 6(15):73-80.

Misha, F., Youshan, B. B., and Hassan, Z., 2015. The Effect of Employees Personality on Organizational Performances: Study on Prudential Assurance Malaysia Berhad (PAMB). International Journal of Accounting, Business, and Management, 1(1):1-9

Moon, H., Dyne, Linn Van. dan Wrobel K. (Ed). 2004. The circumplex Model and The Future of Organizational Citizenship Behaviour Research. Handbook of Organizational Citizenship Behaviour. Nova Science Publishers, Inc.

Mualim, Awang, J., dan Abu Bakar, I., 2014. Pela Gandong Sebagai Pemangkin Toleransi Antara Muslim dan Kristian di Ambon. Jurnal Hadjari, 6(1):43-55.

Muhdar, H. M., Muis, M., Yusuf, R. M., dan Hamid, N., 2015. The Influence of Spiritual Intelligence, Leadership, and Oragnizational Culture on Organizational Citizenship Behavior and Employee Performance (A Study on Islamic Banks in Makassar, South Sulawesi Province, Indonesia). The International Journal of Business and Management, 3(1):297-314

Pattiselanno, J.Th.F., 1999. Tradisi Uli, Pela dan Gandong Pada Masyarakat Seram, Ambon, dan Uliase. Antropologi Indonesia, 58:58-69

Piris, S. dan Tilaar, S. 2014. Graha Wisata Adat Pela Gandong di Maluku (Simbiosis Mutualisme).

Podsakoff, P.M., Ahaerne M., dan MacKenzie S.B. 1997. Organizational Citizenship Behaviour and the Quantity and Quality of Work Group Performance. Journal of Applied Psychology, 82(2):262-270.

Podsakoff, P.M., Mackenzie, S.B., Paine J.B. dan Bachrach D.G., 2000. Organizational Citizenship Behaviours: A Critical Review of the Theoretical and Empirical Literature and Suggestions for Future Research. Journal of Management, 26(3):513-563. 
Ralahallo, R.N. 2009. Kultur Damai Berbasis Tradisi Pela Dalam Perspektif Psikologis Sosial. Jurnal Psikologi, 36(2):177-188

Rashidi, P. R., dan Tafreshi, S. M., 2015. Explanation of the Relationship Between Personality Dimensions and Organizational Citizenship Behavior Among Nurses Of The Hospital Of Torbat-E Haydarieh City. Indian Journal of Fundamental and Applied Life Sciences, 5 (S1):5401-5410.

Robbins, S.P. dan Judge, T. A. 2014a. Perilaku Organisasi - Organizational Behaviour. Buku 1, Edisi 12. Jakarta : Salemba Empat.

Robbins, S.P. dan Judge, T. A. 2014b. Perilaku Organisasi - Organizational Behaviour. Buku 2, Edisi 12. Jakarta : Salemba Empat.

Sahusilawane, F. 2004. Sejarah Lahirnya Pela dan Gandong Antar Negeri-negeri Di Pulau Ambon. Laporan Penelitian Sejarah dan Nilai Tradisional Ambon. Ambon : Balai Kajian Sejarah dan Nilai Tradisional Ambon.

Sani, A dan Maharani, V., 2012. The Impact of Transformational Leadership and Organizational Commitment on Job Performances with the Among Lecturer of Faculty in the Islamic Maulana Malik Ibrahim Malang University: The Mediating Effects of Organizational Citizenship Behavior. International Journal of Academic Research, 4(4):99-103

Sholeh, B., 2013. The Dynamics of Muslim and Christian Relations in Ambon, Easter Indonesia. International Journal of Bussines and School Sciences, 4(3):303311.

Sjahruddin, H., Armanu., Sudiro. A., dan Normijati, 2013. Personality Effect on Organizational Citizenship Behaviour (OCB): Trust in Manager and Organizational Commitment Mediator of Organizational Justice in Makassar City Hospitals (Indonesia). European Journal of Business and Management, 5(9):95-104.

Sonnentag, S., dan Frese, M. 2002. Psychological Management of Individual Performance. Willey Handbook in the Psychology of Management in Organization. John Willey \& Sons, Ltd.

Tsui, A. S., Peare, J. L., Porter, L. W., dan Tripoli, A.M., 1997. Alternative Approach to the Employee-Organizational Relationship: Does Investment in Employees Pay off?. The Academy of Management Journal, 40(5):1089-1121

Tuhuteru, L., 2014. Pembinaan Nilai-Nilai Demokrasi Dalam Budaya Lokal Pada Masyarakat Pasca Konflik Sosial Ambon. Jurnal Pendidikan "Jendela Pengetahuan", 7(17):29-39

Uneputty, T. J. A. 1996. Perwujudan Pela Dalam Kehidupan Sosial Masyarakat Maluku. Ambon : Bagian Proyek Pengkajian dan Pembinaan Nilai-nilai Budaya Maluku. 
Xian Xu, 2004. OCB Through Cultural Lenses: Exploring the Relations among Personality, OCB, and Cultural Values. Disertasi: University of South Florida.

Yakasai, A. M., and Jan, M. T., 2015. The Impact of Big Five Personality Traits on Salespeople's Performance: Exploring The Moderating Role of Culture. Kuwait Chapter of Arabian Journal Business and Management Review, 4(5):11-26

Yi-Min Li, Ying-Huei Kung, dan Yu-Ying Jan. 2012. Studying the Effect of Hospitality Interns' Personality Traits and their Emotional Labor Over Organization Citizenship Behavior. Pakistan Jornal of Statistics, 28(5):673-686

Yung-Chieh Chien, 2013. Verifying the effect of organizational justice and work values upon organizational performances: using organizational citizenship behavior as the dual mediator. African Journal of Business Management, 7(22):2195-2205 